\title{
PENGARUH PENGGUNAAN ABU TERBANG DAN ZEOLIT TERHADAP KARAKTER SUSUT BETON GEOPOLIMER
}

\author{
Effect of Fly Ash and Zeolite Addition on the Character of \\ Geopolymer Concrete Shrinkage
}

\author{
DANANG N. ARIFIN \\ Pusat Penelitian Geoteknologi Lembaga Ilmu Pengetahuan Indonesia \\ JI. Sangkuriang, Kompleks LIPI, Dago, Kecamatan Coblong, \\ Kota Bandung, Jawa Barat 40135 \\ e-mail: danang.na@gmail.com
}

\begin{abstract}
ABSTRAK
Beton adalah material yang paling banyak digunakan untuk bahan bangunan yang telah banyak mengalami perkembangan dalam pembuatannya. Beton geopolimer merupakan material ramah lingkungan yang dapat dikembangkan sebagai alternatif pengganti beton semen konvensional. Salah satu parameter penting yang harus diperhatikan untuk desain daya tahan struktur beton adalah penyusutan. Permasalahan yang muncul adalah bagaimana mengetahui pengaruh bahan-bahan yang digunakan dalam pembentukan beton terhadap penyusutan beton yang dihasilkan. Tujuan penelitian ini adalah untuk mengetahui pengaruh penggunaan bahan baku abu terbang dan zeolit dengan bahan tambahan abu sekam padi terhadap penyusutan beton geopolimer tanpa semen. Terhadap benda percobaan yang dihasilkan dalam penelitian ini selanjutnya dilakukan pengamatan dan pengukuran susut beton. Hasil pengamatan dan pengukuran menunjukkan bahwa pada perubahan tinggi dan diameter beton geopolimer pada rasio abu terbang dan zeolit yang hampir sama (40: 45) terjadi proses geopolimerisasi yang mengakibatkan adanya penyusutan tinggi dan diameter beton geopolimer lebih besar dibandingkan dengan komposisi yang lain.
\end{abstract}

Kata kunci: abu terbang, geopolimer, susut beton, zeolit.

\begin{abstract}
Concrete is the most widely used building material that has improvement and development in its manufacture. Geopolymer concrete is an environmentally friendly material that can be developed as an alternative to conventional cement concrete. The important parameter that must be considered for designing the durability of concrete structures is shrinkage. The arisen problem is how to understand the effect of the used materials in the formation of concrete against the shrinkage of the produced concrete. The purpose of this study was to determine the effect of using fly ash and zeolite as raw materials along with additional of rice husk ash as ingredient on shrinking geopolymer concrete without cement. The experimental objects produced in this study were observed and measured over concrete shrinkage. The results showed that changes in the height and diameter of geopolymer concrete using fly ash and zeolite with ratio almost the same (40: 45) run into a geopolymerization process which resulted in a higher shrinkage than the other compositions.
\end{abstract}

Keywords: concrete shrinkage, fly ash, geopolymer, zeolite. 


\section{PENDAHULUAN}

Pembangunan gedung dan struktur bangunan sebagian besar tergantung kepada produk semen Portland (Posi $d k k$., 2013). Semen Portland sebagai bahan pengikat utama yang digunakan dalam beton adalah produk industri yang membutuhkan energi cukup tinggi dan menghasilkan emisi CO dalam jumlah besar (Habert, d'Espinose de Lacaillerie dan Roussel, 2011; Shi, Jiménez dan Palomo, 2011). Menurut data dari Direktorat Bina Investasi Infrastruktur, Dirjen Bina Konstruksi Kementerian Pekerjaan Umum dan Perumahan Rakyat dan Asosiasi Semen Indonesia, kapasitas produksi semen nasional mengalami peningkatan dari tahun ke tahun (Dirjen Bina Konstruksi Kementerian Pekerjaan Umum dan Perumahan Rakyat, 2018; Susanti dan Jatmiko, 2018). Produksi semen nasional pada 2010 sebesar 53.010.000 ton sedangkan pada 2017 adalah 107.900.000 ton atau mengalami peningkatan sebesar $103,54 \%$ dan diprediksi akan terus mengalami peningkatan dari tahun ke tahun berikutnya.

Pemanfaatan sifat geopolimer dapat digunakan untuk mengurangi penggunaan semen karena dihasilkan dari produk sampingan industri seperti abu terbang, terak dan lain-lain untuk menggantikan $100 \%$ semen dalam beton (Provis dan van Deventer, 2009). Beton geopolimer merupakan beton geosintetik yang reaksi pengikatannya terjadi melalui reaksi polimerisasi dan bukan melalui reaksi hidrasi seperti beton konvensional (Davidovits, 2005). Beton akan mengalami penyusutan bentuk dan ukuran dalam proses pembentukannya. Penyusutan beton pada usia dini umumnya dianggap sebagai parameter penting untuk desain daya tahan struktur beton (Shi, 1996; Bakharev, Sanjayan dan Cheng, 1999). Salah satu penyebab terjadinya penyusutan beton adalah kehilangan kelembaban. Tingkat kehilangan kelembaban pada usia dini dalam beton tergantung beberapa faktor seperti kelembaban relatif, suhu, rasio air terhadap pengikat, ukuran dan bentuk spesimen (Shi, 1996; Xu dan Van Deventer, 2000; Kumar $d k k ., 2005)$.

Menurut Nawy (1998), susut beton pada dasarnya dibedakan menjadi dua jenis yaitu: susut plastis dan susut pengeringan. Susut plastis terjadi beberapa saat setelah campuran beton dicor ke dalam cetakan sedangkan susut pengeringan terjadi setelah beton mencapai bentuk akhirnya dan proses hidrasi pasta bahan pengikat telah selesai. Menurut SNI 036823-2002, susut kering adalah pengurangan panjang conto benda uji yang diukur sepanjang sumbu memanjang, pengurangan tersebut disebabkan bukan gaya-gaya luar, tetapi akibat keadaan suhu, kelembaban relatif dan penguapan lingkungan. Susut kering tergantung dari lamanya deformasi karena hilangnya air yang disebabkan tegangan hidrostatik pori-pori kapiler kecil dari spesimen beton dan dapat menyebabkan retak parah pada beton yang pada akhirnya memungkinkan masuknya zat agresif ke dalam beton (Deb, Nath dan Sarker, 2015). Beberapa faktor yang memengaruhi perilaku penyusutan beton geopolimer antara lain: sifat agregat, kandungan alkali cair dan air, bahan pengikat dan lingkungan curing (Roy dan Idorn, 1982; Collins dan Sanjayan, 1999; Castel, Foster dan Aldred, 2014).

Permasalahan yang muncul adalah bagaimana mengetahui pengaruh bahan - bahan yang digunakan dalam pembentukan beton dalam penyusutan beton yang dihasilkan, karena merupakan parameter penting untuk desain daya tahan struktur beton. Tujuan penelitian ini adalah untuk mengetahui pengaruh penggunaan bahan baku abu terbang dan zeolit dengan bahan tambahan abu sekam padi terhadap penyusutan beton geopolimer tanpa semen.

\section{METODE}

Bahan baku yang digunakan dalam penelitian ini adalah sisa pembakaran batubara dari PLTU Palabuhanratu, Jawa Barat berupa abu terbang, zeolit alam dari Kecamatan Cikembar, Kabupaten Sukabumi, dengan bahan tambahan berupa abu sekam padi dari Kecamatan Majalaya, Kabupaten Bandung. Pembuatan benda uji diawali dengan melakukan preparasi percontoh bahan baku abu terbang (ukuran-100 mesh), zeolit (ukuran -40 + 80 mesh) dan abu sekam padi (ukuran 50 mesh). Sebagai bahan pengikat digunakan larutan alkali aktivator yang berasal dari natrium silikat $\left(\mathrm{Na}_{2} \mathrm{SiO}_{3}\right)$ dan $\mathrm{NaOH}$. Pencampuran dan pencetakan bahan 
penyusun beton geopolimer menggunakan metode SNI 2493:2011 tentang "Tata cara pembuatan beton dan perawatan benda uji beton di laboratorium" (Badan Standardisasi Nasional, 2011). Waktu curing untuk melakukan pengukuran susut beton yaitu 28 hari. Diagram alir percobaan yang dilakukan ditunjukkan pada Gambar 1.

\section{Pembuatan Benda Uji}

Sebelum dilakukan pembuatan atau pencetakan benda uji beton geopolimer terlebih dahulu ditentukan komposisi penyusun beton geopolimer tersebut yang berasal dari bahan baku dan bahan tambahan yang digunakan. Penyusunan komposisi beton geopolimer menggunakan rasio $\mathrm{Al} / \mathrm{Si}$ dari masing-masing bahan yang digunakan. Dalam menentukan formulasi campuran beton geopolimer digunakan variabel tetap dan variabel berubah antara lain : perbandingan air/alkali-activator $=1: 4$ (Agustinus, 2007), perbandingan natrium silikat/ $\mathrm{NaOH}=2,5: 1$ (Hardjito dkk., 2004), konsentrasi $\mathrm{NaOH}$ yang digunakan 8M (Ravikumar, Peethamparan dan Neithalath, 2010) dan abu sekam padi yang digunakan adalah 15\% (Ganesan, Rajagopal dan Thangavel, 2008). Natrium hidroksida $(\mathrm{NaOH})$ berfungsi untuk mereaksikan unsurunsur $\mathrm{Al}$ dan $\mathrm{Si}$ dengan menambahkan ion $\mathrm{Na}^{+}$. Tabel 1 menunjukkan formulasi beton geopolimer berbahan abu terbang, zeolit dan abu sekam padi.

Setelah dilakukan formulasi terhadap komposisi beton geopolimer kemudian dilakukan proses pencetakan benda uji beton geopolimer pada cetakan silinder berukuran $4,5 \mathrm{~cm} \times 9 \mathrm{~cm}$. Langkah-langkah pembuatan percontoh beton geopolimer adalah sebagai berikut :

a. Bahan baku dan bahan tambahan masingmasing diukur dan ditimbang sesuai dengan formulasi komposisi yang telah ditentukan;

b. Membuat larutan alkali activator dari natrium silikat, $\mathrm{NaOH}$ dan air:

- Air dicampur dengan $\mathrm{NaOH}$ kemudian diaduk hingga larut selama \pm 5 menit;

- Natrium silikat ditambahkan ke dalam larutan air dan $\mathrm{NaOH}$ kemudian diaduk selama \pm 5 menit;

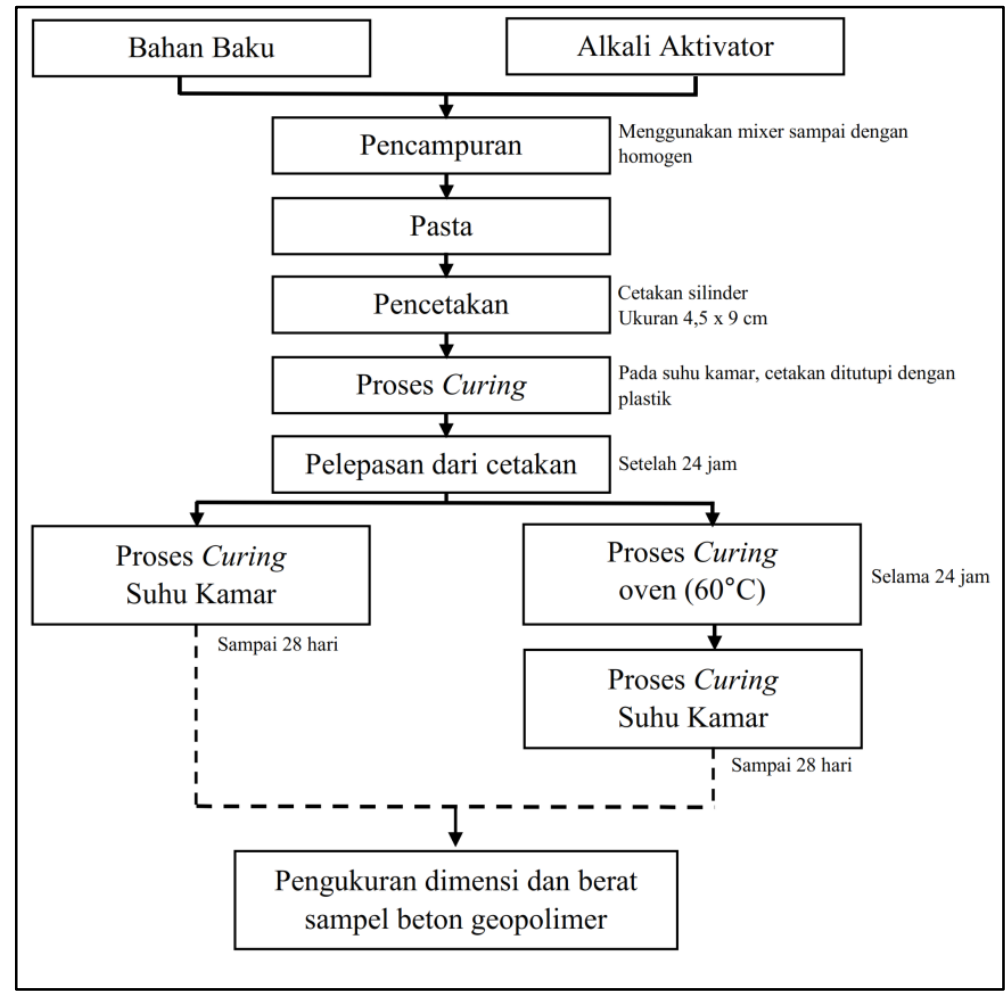

Gambar 1. Diagram alir percobaan 
Tabel 1. Formulasi komposisi beton geopolimer

\begin{tabular}{|c|c|c|c|c|c|c|c|c|}
\hline \multirow[b]{2}{*}{ Komposisi } & \multirow[b]{2}{*}{$\begin{array}{c}\text { Zeolit } \\
(\%)\end{array}$} & \multirow{2}{*}{$\begin{array}{c}\text { Abu } \\
\text { SekamPadi } \\
(\%)\end{array}$} & \multirow{2}{*}{$\begin{array}{c}\text { Abu } \\
\text { Terbang } \\
(\%) \\
\end{array}$} & \multirow[b]{2}{*}{$\begin{array}{l}\text { Rasio } \\
\mathrm{Al} / \mathrm{Si}\end{array}$} & \multicolumn{2}{|c|}{ Alkali-activator } & \multirow[b]{2}{*}{$\begin{array}{l}\text { Air } \\
(\%)\end{array}$} & \multirow{2}{*}{$\begin{array}{c}\text { Rasio } \\
\text { Air/alkali- } \\
\text { activator }\end{array}$} \\
\hline & & & & & $\begin{array}{l}\text { Sodium } \\
\text { silikat (\%) }\end{array}$ & $\begin{array}{c}\mathrm{NaOH} \\
(\%)\end{array}$ & & \\
\hline BG-1 & 10 & 15 & 75 & $1: 2$ & 57 & 23 & 20 & $1: 4$ \\
\hline BG-2 & 20 & 15 & 65 & $1: 2,5$ & 57 & 23 & 20 & $1: 4$ \\
\hline BG-3 & 30 & 15 & 55 & $1: 3$ & 57 & 23 & 20 & $1: 4$ \\
\hline BG-4 & 45 & 15 & 40 & $1: 3,5$ & 57 & 23 & 20 & $1: 4$ \\
\hline BG-5 & 60 & 15 & 25 & $1: 4$ & 57 & 23 & 20 & $1: 4$ \\
\hline
\end{tabular}

c. Bahan baku (abu terbang dan zeolit) dan bahan tambahan berupa abu sekam padi dimasukkan perlahan ke dalam larutan alkali activator kemudian diaduk sampai campuran menjadi homogen ( \pm 5 menit);

d. Pasta yang terbentuk kemudian dituangkan ke dalam cetakan silinder;

e. Percontoh yang telah tercetak kemudian didiamkan pada suhu ruangan dan ditutup menggunakan plastik tipis untuk mencegah hilangnya kelembaban pada percontoh selama 24 jam;

f. Percontoh dikeluarkan dari cetakan setelah 24 jam:

- Untuk percontoh yang mendapat perlakuan pemanasan pada oven, dimasukkan ke dalam oven sesuai dengan suhu yang telah ditentukan yaitu $60^{\circ} \mathrm{C}$ selama 24 jam secara bertahap, kemudian dilakukan proses curing pada suhu ruangan sampai dengan 28 hari;

- Untuk percontoh yang tidak dipanaskan, dilakukan proses curing pada suhu ruangan sampai dengan 28 hari;

Abu sekam padi merupakan bahan tambahan yang efektif pada geopolimer ketika digunakan dalam jumlah yang tepat (Venkatanarayanan dan Rangaraju, 2015). Karena abu sekam padi mengandung silika dan alumina dalam jumlah signifikan, material ini sesuai untuk menghasilkan geopolimer (Chindaprasirt $d k k$., 2009; He dkk., 2013). Abu sekam padi digunakan sebagai bahan pozolan reaktif yang sangat tinggi untuk meningkatkan struktur mikro pada pembuatan beton geopolimer.

Proses curing merupakan proses pengeringan bahan-bahan penyusun komposit, baik matriks maupun bahan tambahannya. Proses ini dilakukan agar campuran benda uji beton geopolimer dapat terbentuk dengan baik.
Caranya dapat dilakukan dengan beberapa cara yaitu: pengeringan udara (suhu ruang) atau dimasukkan ke dalam oven sesuai suhu yang diinginkan.

\section{HASIL DAN PEMBAHASAN}

Hasil analisis atomic absorption spectrophotometer (AAS) bahan baku dan bahan tambahan menggunakan AA-7000, Atomic Absorption Spectrophotometer, Shimadzu, Serial No. A306649 dapat dilihat pada Tabel 2.

Tabel 2. Hasil analisis AAS bahan baku dan bahan tambahan pembuatan beton geopolimer

\begin{tabular}{llrrr}
\hline No & Komponen & \multicolumn{1}{c}{$\begin{array}{c}\text { Abu } \\
\text { terbang } \\
(\%)\end{array}$} & \multicolumn{1}{c}{$\begin{array}{r}\text { Zeolit } \\
(\%)\end{array}$} & $\begin{array}{r}\text { Abu } \\
\text { Sekam } \\
\text { Padi }(\%)\end{array}$ \\
\hline 1. & $\mathrm{SiO}_{2}$ & 48,96 & 67,65 & 87,48 \\
2. & $\mathrm{TiO}_{2}$ & 1,47 & 0,57 & 0,27 \\
3. & $\mathrm{Al}_{2} \mathrm{O}_{3}$ & 26,38 & 11,27 & 1,66 \\
4. & $\mathrm{Fe}_{2} \mathrm{O}_{3}$ & 9,82 & 1,02 & 0,99 \\
5. & $\mathrm{MnO}$ & 0,85 & 0,05 & 0,1 \\
6. & $\mathrm{MgO}$ & 0,59 & 0,15 & 0,24 \\
7. & $\mathrm{CaO}$ & 0,29 & 0,03 & ttd \\
8. & $\mathrm{K} 2 \mathrm{O}$ & 0,51 & 1,73 & 2,76 \\
9. & $\mathrm{Na} 2 \mathrm{O}$ & 1,51 & 2,65 & 0,14 \\
10. & $\mathrm{P}_{2} \mathrm{O} 5$ & 6,76 & 0,48 & 1,53 \\
11. & $\mathrm{H}_{2} \mathrm{O}-$ & 0,58 & 8,02 & 2,06 \\
12. & $\mathrm{H}_{2} \mathrm{O}+$ & 1,61 & 3,35 & 2,15 \\
13. & L.O.l. & 2,75 & 14,23 & 4,66 \\
\hline
\end{tabular}

*) ttd : tidak terdeteksi

Hasil analisis AAS menunjukkan bahwa zeolit mengandung $\mathrm{SiO}_{2}$ paling besar $(67,65 \%)$ dan $\mathrm{Al}_{2} \mathrm{O}_{3}$ sebesar $11,27 \%$. Kandungan $\mathrm{CaO}$ dalam abu terbang terdeteksi sebanyak 0,29 $\%$ sehingga abu terbang yang digunakan dalam penelitian ini termasuk dalam kelas abu terbang $F$ (ASTM C618-12a, 2012). Abu 
terbang kelas $\mathrm{F}$ merupakan abu terbang sisa pembakaran batubara yang memiliki kandungan $\mathrm{CaO}$ kurang dari $10 \%$. Abu terbang jenis ini memiliki sifat pozzolan sehingga baik jika digunakan sebagai material pembentuk beton geopolimer.

Hasil pencetakan benda uji beton geopolimer (Gambar 2) menunjukkan bahwa untuk seluruh formulasi komposisi beton geopolimer yang dibuat dapat dibentuk/dicetak menjadi beton geopolimer dengan presisi dan bentuk yang baik.

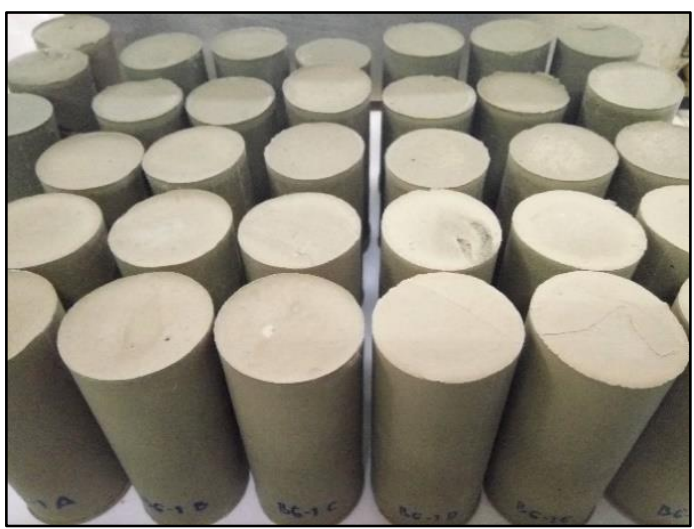

Gambar 2. Hasil pencetakan benda uji beton geopolimer.

Setelah benda uji beton geopolimer dilakukan proses curing, kemudian dilakukan pengukuran baik dimensi maupun berat terhadap benda uji beton geopolimer tersebut (Gambar 3).

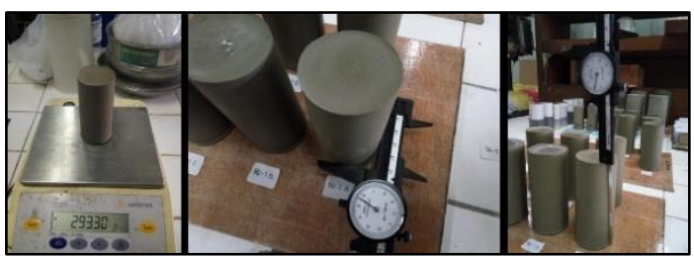

Gambar 3. Pengukuran dimensi dan berat benda uji beton geopolimer.

\section{Perubahan Ukuran Dimensi dan Berat Benda Uji Beton Geopolimer Selama Waktu Curing}

Benda uji beton geopolimer yang telah dilakukan proses curing selama 28 hari, baik yang dipanaskan pada suhu $60^{\circ} \mathrm{C}$ maupun yang tidak dipanaskan, akan mengalami penyusutan ukuran (tinggi dan diameter) dan berat. Perubahan diameter diukur dalam rentang waktu tertentu yaitu pada hari ke-2 (dua), 3 (tiga), 7 (tujuh), 15 (lima belas), 22 (dua puluh dua) dan 27 (dua puluh tujuh). Penyusutan beton geopolimer terjadi karena hilangnya kelembaban pada benda uji yang disebabkan penguapan pada campuran beton geopolimer selama dilakukan proses curing. Selain itu juga disebabkan perubahan kondisi campuran beton menjadi lebih kering selama proses curing sehingga mempengaruhi volume beton geopolimer.

\section{Perubahan Diameter}

Hasil pengukuran perubahan diameter terhadap benda uji beton geopolimer pada proses curing suhu kamar dapat dilihat pada Gambar 4. Sedangkan hasil pengukuran perubahan diameter terhadap benda uji beton geopolimer pada proses curing suhu $60^{\circ} \mathrm{C}$ dapat dilihat pada Gambar 5.

Dari Gambar 4. dapat dilihat bahwa beton geopolimer yang dilakukan proses curing pada suhu kamar pada hari kedua dan ketiga relatif belum mengalami perubahan. Hal ini kemungkinan disebabkan karena proses pengeringan pada suhu kamar belum terlalu berpengaruh terhadap penyusutan diameter benda uji karena waktu yang singkat.

Pada hari ketujuh pengukuran, terjadi penurunan diameter yang cukup signifikan. $\mathrm{Hal}$ ini disebabkan proses pengeringan sudah berjalan sehingga diameter masing-masing benda uji mengalami penyusutan. Kemudian pengukuran pada hari kelima belas, kedua puluh dua dan ke dua puluh tujuh diameter benda uji beton geopolimer relatif tidak mengalami perubahan. Hal tersebut disebabkan proses pengeringan telah mencapai titik maksimal pada hari ketujuh, sehingga setelah hari ketujuh tersebut benda uji beton geopolimer sudah tidak mengalami penyusutan diameter.

Komposisi beton geopolimer BG-4 (45\% zeolit dan $40 \%$ abu terbang) mengalami perubahan diameter paling besar yaitu 0,24\% pada hari ke-27. Hal tersebut dipengaruhi oleh zeolit yang memiliki sifat sangat molekuler, kapasitas penyerapan tinggi pada tekanan rendah dalam kisaran suhu 10 - 
$150^{\circ} \mathrm{C}$ (Wojsz dan Rozwadowski, 1987). Sedangkan komposisi beton geopolimer BG-1 (10\% zeolit dan $75 \%$ abu terbang) dan BG-2 (20\% zeolit dan $65 \%$ abu terbang) mengalami perubahan diameter paling kecil yaitu $0,20 \%$ pada hari ke-27. Hal tersebut dipengaruhi oleh penggunaan abu terbang yang berperan mengurangi panas hidrasi, sehingga dapat memengaruhi penyusutan beton selama berlangsungnya proses curing.

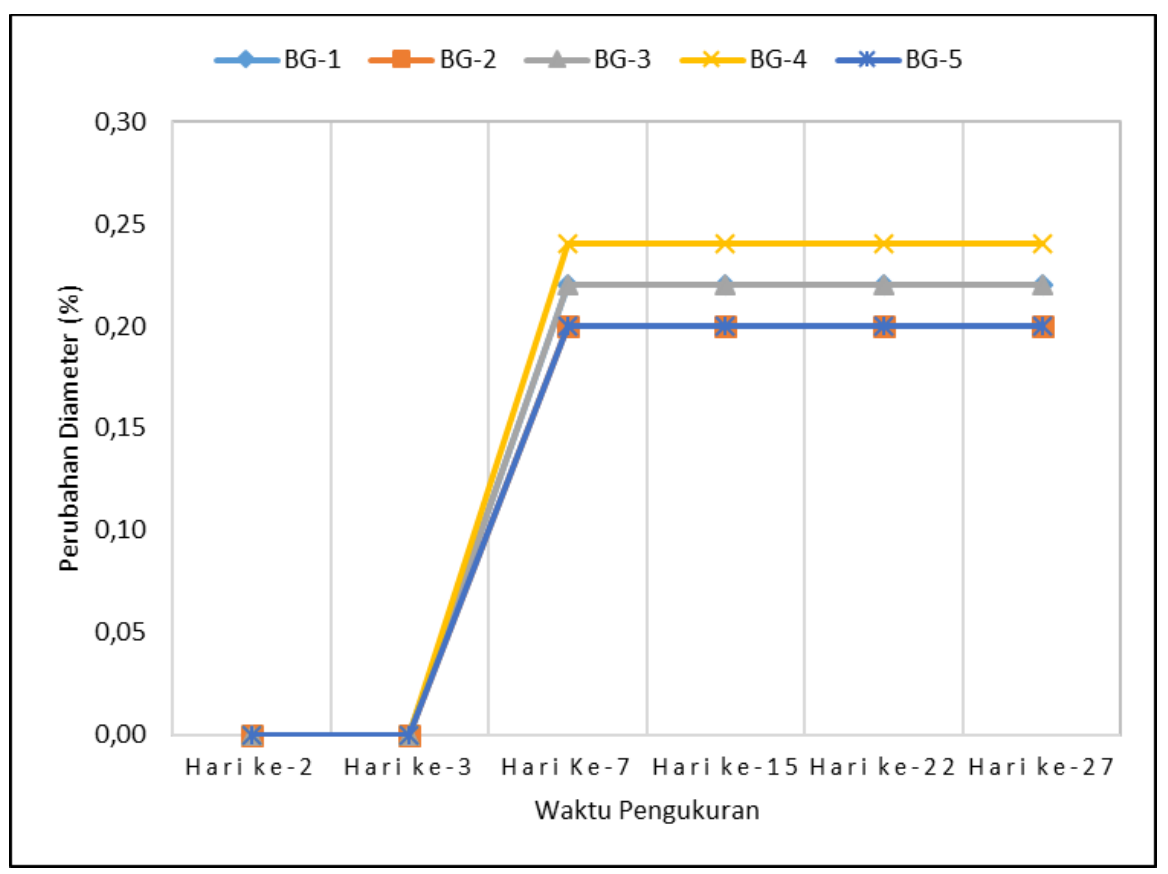

Gambar 4. Grafik perubahan diameter percontoh beton geopolimer pada proses curing suhu ruang.

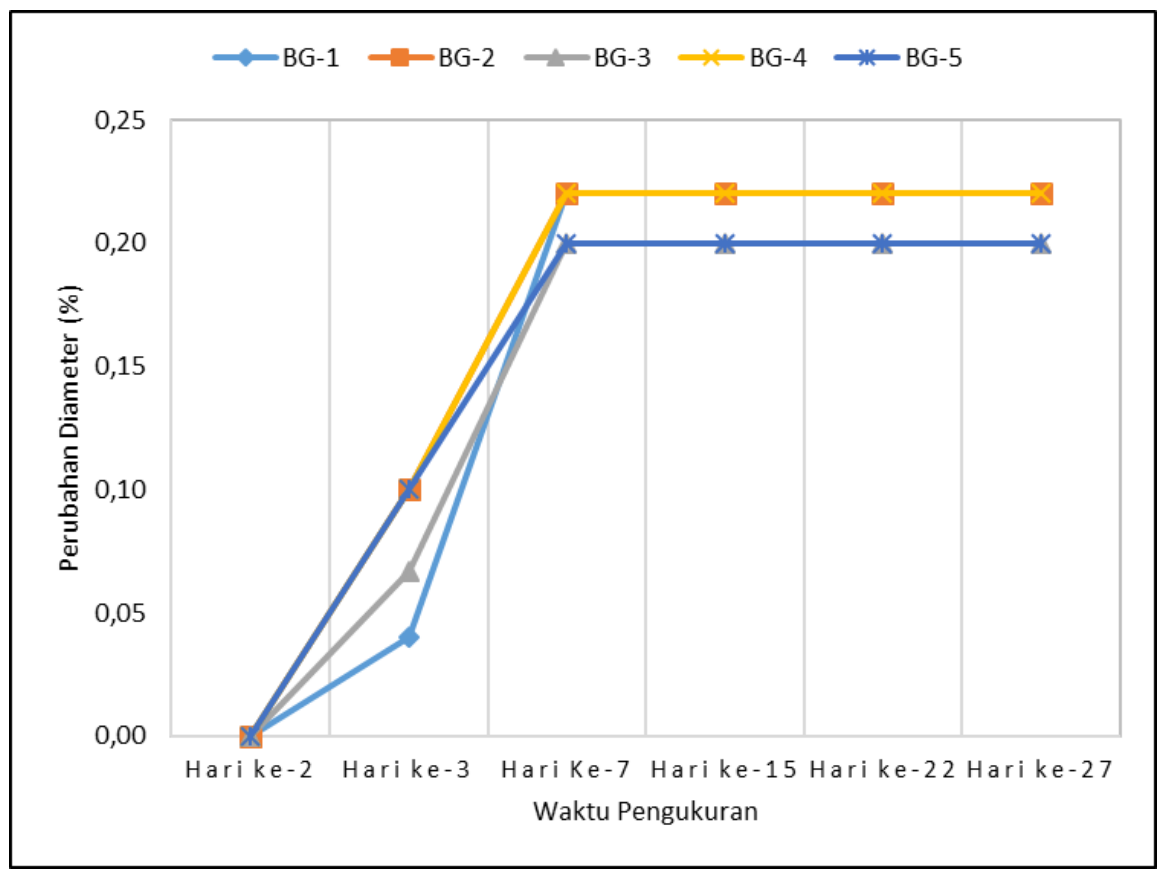

Gambar 5. Grafik perubahan diameter percontoh beton geopolimer pada proses curing suhu $60^{\circ} \mathrm{C}$ 
Perubahan percontoh beton geopolimer yang dilakukan pada suhu $60^{\circ} \mathrm{C}$ seperti yang ditampilkan pada Gambar 5 menunjukan kecenderungan yang sama, yaitu proses pengeringan telah mencapai titik maksimal pada hari ketujuh, sehingga setelah hari ketujuh tersebut benda uji beton geopolimer sudah tidak mengalami penyusutan diameter.

Komposisi beton geopolimer BG-1, BG-2 dan BG-4 mengalami perubahan diameter paling besar yaitu $0,22 \%$ pada hari ke-27. Hal ini terjadi karena adanya kehilangan kelembaban pada benda uji karena proses pemanasan pada suhu $60^{\circ} \mathrm{C}$. Pada pemanasan suhu $60^{\circ} \mathrm{C}$, terjadi peningkatan laju disolusi prekursor alumina dan silika dari abu terbang melalui polarisasi ion hidroksida (Tangchirapat $d k k$., 2008). Sedangkan komposisi beton geopolimer BG-3 dan BG-5 mengalami perubahan diameter paling kecil yaitu $0,20 \%$ pada hari ke-27. Selama proses hidrasi air yang diserap oleh zeolit dilepaskan ke dalam matriks, oleh karena itu komposisi beton geopolimer dengan campuran zeolit dapat mempertahankan kelembaban sehingga memengaruhi penyusutan beton.

\section{Perubahan Tinggi}

Hasil pengukuran perubahan tinggi terhadap benda uji beton geopolimer dapat dilihat pada Gambar 6. Sedangkan hasil pengukuran perubahan diameter terhadap benda uji beton geopolimer pada proses curing suhu $60^{\circ} \mathrm{C}$ dapat dilihat pada Gambar 7.

Pengukuran tinggi terhadap benda uji beton geopolimer yang dilakukan proses curing pada suhu kamar menunjukkan kecenderungan yang hampir sama, yaitu pada pengukuran hari ketiga dan hari ketujuh, benda uji beton geopolimer mengalami perubahan tinggi pada masing-masing komposisi. Kemudian mengalami titik maksimal pada hari ketujuh, benda uji beton geopolimer cenderung sudah tidak mengalami penyusutan tinggi.

Komposisi beton geopolimer BG-4 mengalami perubahan tinggi paling besar yaitu 0,68\% pada hari ke-27, sedangkan komposisi beton geopolimer BG-5 mengalami perubahan tinggi paling kecil yaitu 0,4\% pada hari ke-27.

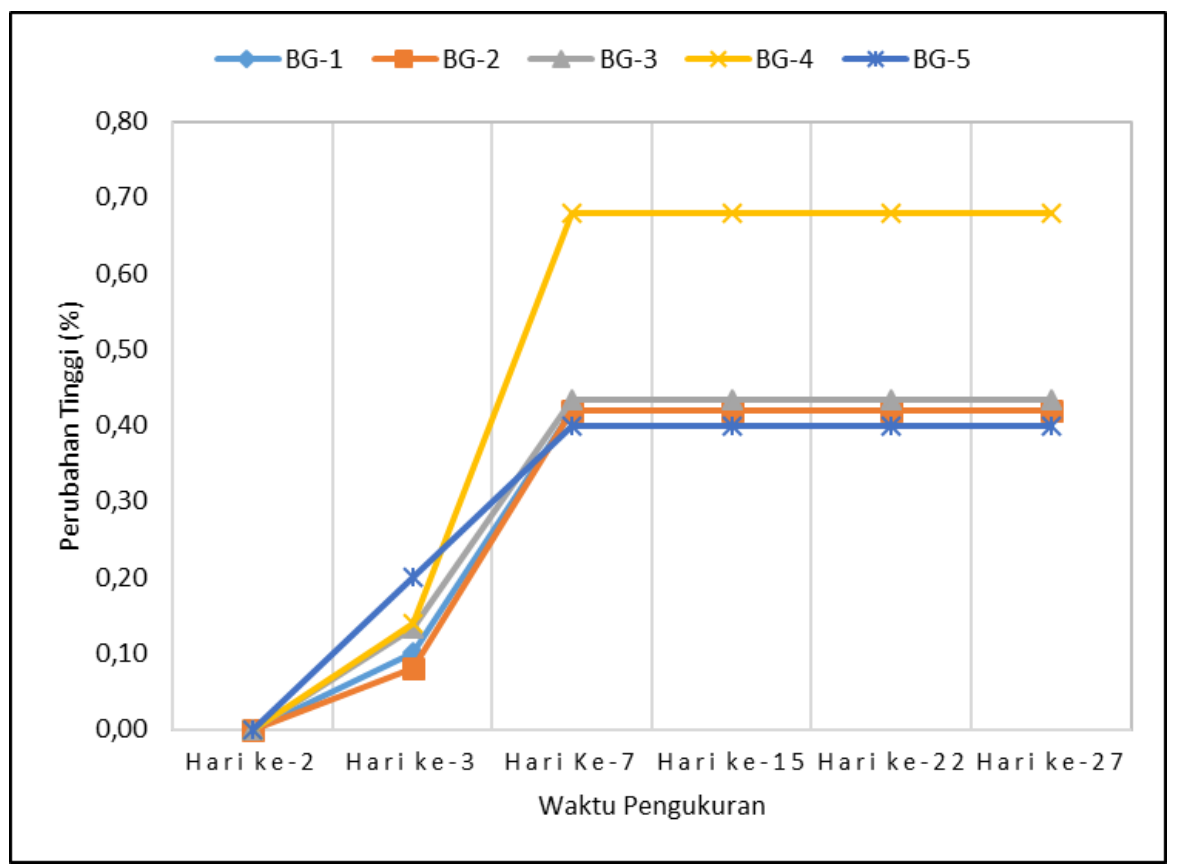

Gambar 6. Grafik perubahan tinggi percontoh beton geopolimer pada proses curing suhu ruang 


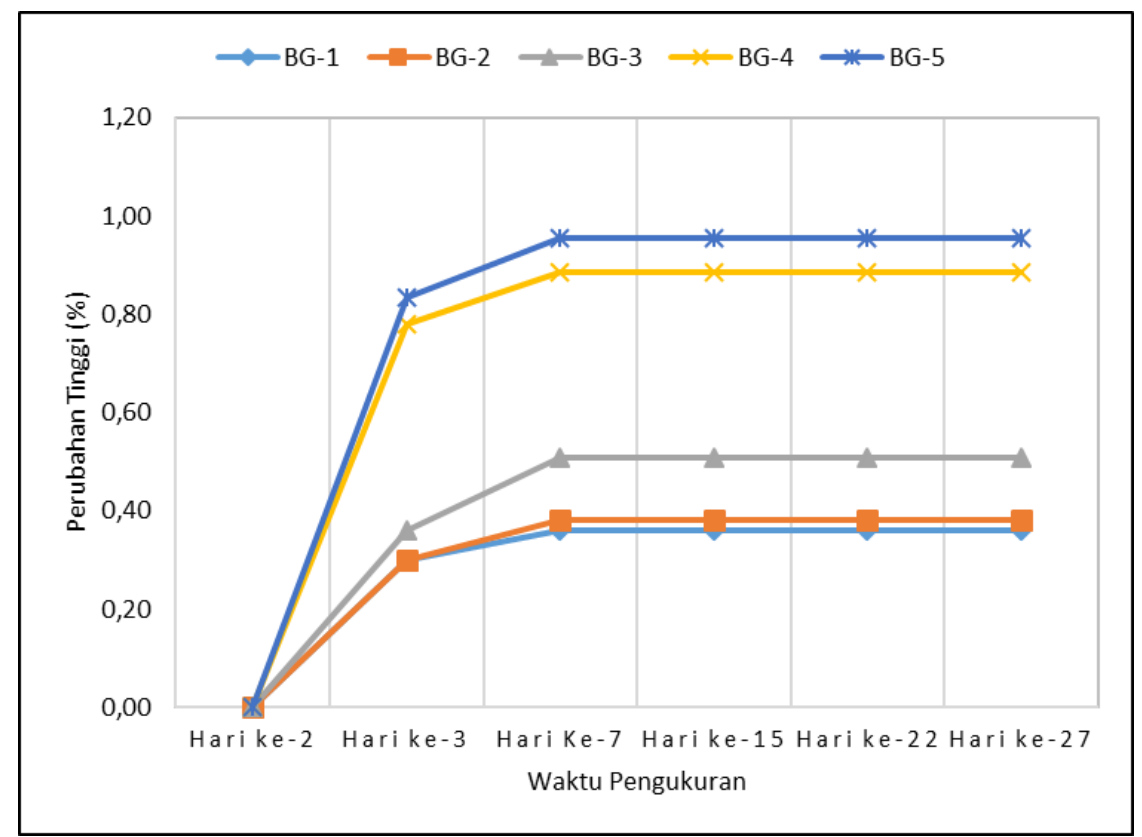

Gambar 7. Grafik perubahan tinggi percontoh beton geopolimer pada proses curing suhu $60^{\circ} \mathrm{C}$

Pada pengukuran perubahan tinggi benda uji beton geopolimer yang dilakukan proses curing pada suhu $60^{\circ} \mathrm{C}$ menunjukkan bahwa pada hari ketiga pengukuran mengalami penyusutan yang relatif sama kemudian perlahan sampai dengan hari ketujuh telah mencapai titik maksimal penyusutan tinggi.

Komposisi beton geopolimer BG-5 mengalami perubahan tinggi paling besar yaitu 0,95\% pada hari ke-27. Suhu pengeringan memiliki pengaruh yang signifikan terhadap penyusutan beton (Deb, Nath dan Sarker, 2015). Pori-pori yang terbentuk pada benda uji juga memiliki efek langsung terhadap susut pengeringan beton geopolimer. Sedangkan komposisi beton geopolimer BG-1 mengalami perubahan tinggi paling kecil yaitu 0,36\% pada hari ke-27. Penggunaan abu terbang pada pembuatan beton geopolimer cenderung mengurangi penyusutan beton.

\section{Perubahan Berat}

Hasil pengukuran perubahan berat terhadap benda uji beton geopolimer yang dilakukan proses curing pada suhu ruang dapat dilihat pada Gambar 8. Sedangkan Hasil pengukuran perubahan berat terhadap benda uji beton geopolimer pada proses curing suhu $60^{\circ} \mathrm{C}$ dapat dilihat pada Gambar 9.
Perubahan berat percontoh beton geopolimer yang dilakukan proses curing pada suhu ruang telihat terjadi penurunan secara perlahanlahan atau lambat dan cenderung stabil pada hari ke-22. Hal ini terjadi karena proses pengeringan pada percontoh beton geopolimer tersebut terjadi pada suhu ruang yang pengaruhnya tidak terlalu signifikan terhadap perubahan berat percontoh beton geopolimer. Komposisi beton geopolimer BG-5 mengalami perubahan berat paling besar yaitu $0,41 \%$ pada hari ke-27, sedangkan komposisi beton geopolimer BG-2 mengalami perubahan berat paling kecil yaitu $0,25 \%$ pada hari ke-27.

Perubahan berat percontoh beton geopolimer yang dilakukan proses curing pada suhu $60^{\circ} \mathrm{C}$ dapat dilihat bahwa terjadi penurunan secara cepat pada hari ketiga kemudian menurun secara perlahan-lahan dan cenderung stabil pada hari ke-22. Penurunan berat secara cepat pada hari ketiga kemungkinan dipengaruhi oleh proses pemanasan percontoh beton geopolimer pada suhu $60^{\circ} \mathrm{C}$, kemudian menurun secara perlahan-lahan karena proses pengeringan sudah dilakukan pada suhu ruang sehingga pengaruhnya tidak terlalu signifikan terhadap perubahan berat percontoh beton geopolimer. 


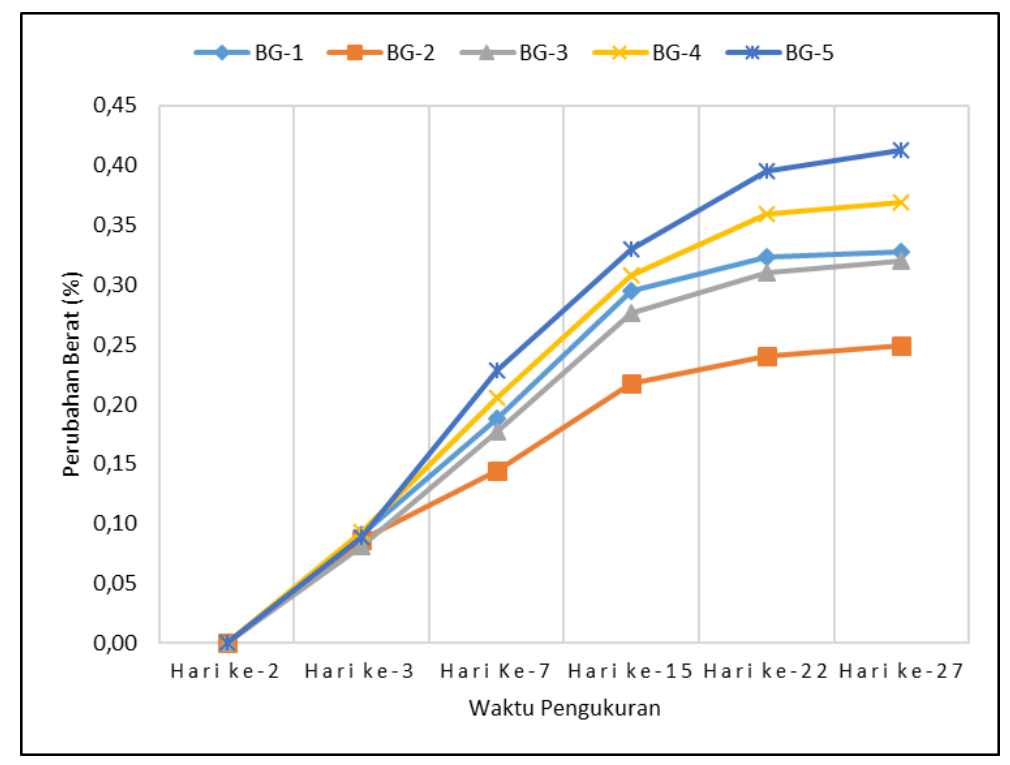

Gambar 8. Grafik perubahan berat percontoh beton geopolimer pada proses curing suhu ruang.

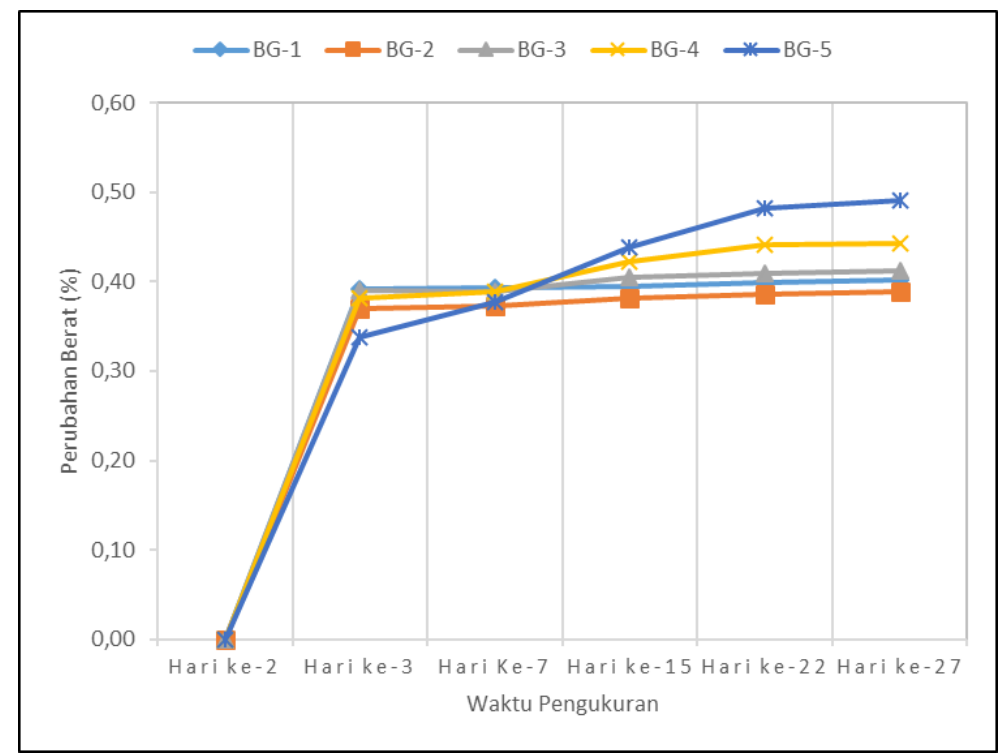

Gambar 9. Grafik perubahan berat percontoh beton geopolimer pada proses curing suhu $60^{\circ} \mathrm{C}$.

Komposisi beton geopolimer BG-5 mengalami perubahan berat paling besar yaitu $0,49 \%$ pada hari ke-27, sedangkan komposisi beton geopolimer BG-2 mengalami perubahan berat paling kecil yaitu 0,39\% pada hari ke-27.

Secara keseluruhan perubahan berat benda uji beton geopolimer dipengaruhi oleh perubahan volume, kemudian perubahan volume dipengaruhi oleh perubahan diameter dan tinggi, sehingga beton geopolimer yang mengalami perubahan tinggi dan diameter yang besar akan mengalami perubahan berat yang besar pula. Demikian juga dengan beton geopolimer yang mengalami perubahan tinggi dan diameter yang kecil akan mengalami perubahan berat yang kecil juga.

Pada saat berlangsungnya proses curing beton geopolimer, zeolit berperan sebagai penyerap air yang kemudian didistribusikan ke seluruh bagian beton karena kemampuan adsorpsi zeolit yang tinggi. Air yang teradsopsi dalam partikel-partikel ini ditarik ke dalam kapiler 
yang terbentuk selama tahap awal proses pencampuran beton (Lura, Jensen dan Igarashi, 2007; Liu $d k k ., 2017)$. Proses yang terjadi tersebut membantu mencegah beton mengering sendiri sehingga penyusutan autogeneous beton dapat dikurangi (Tran dkk., 2019).

Abu terbang yang digunakan dalam penelitian ini selain berfungsi sebagai bahan pozolan (mempunyai sifat pozolanik) juga berperan untuk mengurangi panas hidrasi, sehingga dapat mengurangi terjadinya retak yang memengaruhi penyusutan beton selama proses setting dan pengerasan beton (Davidovits, 2011). Kandungan Si dan Al yang terdapat dalam abu terbang terpolimerisasi dengan larutan cair sehingga membentuk blok yang mengandung pengikat geopolimer dan menyebabkan peningkatan kandungan agregat beton yang akan memengaruhi proses penyusutan beton geopolimer tersebut (Wallah, 2009).

Sampai dengan saat ini belum ada aturan baku yang dapat digunakan sebagai acuan dalam menentukan batas nilai penyusutan beton geopolimer. Standar yang ada saat ini digunakan untuk menentukan batas nilai penyusutan beton hanya untuk beton konvensional (menggunakan bahan pengikat semen). Bahan penyusun dan reaksi yang terjadi selama proses pembentukan beton konvensional relatif berbeda dengan proses pembentukan beton geopolimer tanpa semen.

Hasil penelitian ini dapat menjadi alternatif dalam pembuatan beton non konvensional. Selain itu juga dapat digunakan untuk meningkatkan nilai tambah bahan-bahan penyusunnya (abu terbang, zeolit) menjadi material fungsional berupa beton geopolimer.

\section{KESIMPULAN}

Dari penelitian yang telah dilakukan dapat dismpulkan bahwa:

1. Perubahan diameter rata-rata baik dalam proses curing suhu ruang maupun suhu $60^{\circ} \mathrm{C}$ adalah $0,2 \%$, perubahan diameter yang tertinggi adalah komposisi BG-4 yang tersusun dari $45 \%$ zeolit dan $40 \%$ abu terbang.
2. Perubahan tinggi beton geopolimer pada proses curing suhu ruang rata-rata adalah $0,47 \%$, perubahan tertinggi komposisi BG4 (45\% zeolit dan $40 \%$ abu terbang) dan terendah komposisi BG-5 $(60 \%$ zeolit dan $25 \%$ abu terbang. Pada proses curing suhu $60^{\circ} \mathrm{C}$ perubahan tinggi rata-rata adalah $0,62 \%$, perubahan tertinggi komposisi BG$5(60 \%$ zeolit dan $25 \%$ abu terbang) dan BG-4 (45\% zeolit dan $40 \%$ abu terbang) dan terendah komposisi BG-1 (10\% zeolit dan $75 \%$ abu terbang);

3. Pada perubahan tinggi dan diameter komposisi BG-4 (45\% zeolit dan 40\% abu terbang) mengalami perubahan paling tinggi. Hal ini menunjukkan bahwa penggunaan abu terbang dan zeolit yang hampir sama $(40: 45)$, mengalami proses geopolimerisasi yang mengakibatkan penyusutan tinggi dan diameter lebih besar dibandingkan dengan komposisi yang lain.

\section{UCAPAN TERIMA KASIH}

Terimakasih kepada Prof (Ris). Dr. Ir. Eko Tri Sumarnadi Agustinus, MT. dari Pusat Penelitian Geoteknologi, Lembaga IImu Pengetahuan Indonesia yang telah memberikan saran dan masukan selama kegiatan penelitian.

\section{DAFTAR PUSTAKA}

Agustinus, E. T. S. (2007) "Bata keramik suhu bakar rendah sebagai bahan bangunan konstruksi ringan," in Prosiding Seminar Geoteknologi Kontribusi Ilmu Kebumian Dalam Pembangunan Berkelanjutan. Bandung: LIPI Press, hal. 207-214.

ASTM C618-12a (2012) Standard specification for coal fly ash and raw or calcined natural Pozzolan for use in concrete. West Conshohocken: ASTM International. doi: 10.1520/C0618-12A.

Badan Standardisasi Nasional (2011) SNI 24932011: Tata cara pembuatan dan perawatan benda uji beton di laboratorium. Jakarta.

Bakharev, T., Sanjayan, J. G. dan Cheng, Y.-B. (1999) "Alkali activation of Australian slag cements," Cement and Concrete Research, 29(1), hal. 113-120. doi: 10.1016/S00088846(98)00170-7. 
Castel, A., Foster, S. dan Aldred, J. (2014) "Timedependent behavior of a class $F$ fly ashabu terbang based geopolymer concrete," in International Conference on Non-Traditional Cement and Concrete V. Brno: Brno University of Technology, hal. 25-28.

Chindaprasirt, P., Jaturapitakkul, C., Chalee, W. dan Rattanasak, U. (2009) "Comparative study on the characteristics of fly ash and bottom ash geopolymers," Waste Management, 29(2), hal. 539-543.

doi: 10.1016/j.wasman.2008.06.023.

Collins, F. dan Sanjayan, J. G. (1999) "Strength and shrinkage properties of alkali-activated slag concrete containing porous coarse aggregate," Cement and Concrete Research, 29(4), hal. 607-610. doi: 10.1016/S00088846(98)00203-8.

Davidovits, J. (2005) "The poly (sialate) terminology: A very useful and simple model for the promotion and understanding," in Proceedings of the World Congress Geopolymer 2005: Geopolymer chemistry and sustainable development. Saint Quentin: Institut Géopolymère, hal. 9-15.

Davidovits, J. (2011) Geopolymer: Chemistry and applications. 3rd Ed. Saint Quentin: Institut Géopolymère.

Deb, P. S., Nath, P. dan Sarker, P. K. (2015) "Drying shrinkage of slag blended fly ash geopolymer concrete cured at room temperature," Procedia Engineering, 125, hal. 594-600.

doi: 10.1016/j.proeng.2015.11.066.

Dirjen Bina Konstruksi Kementerian Pekerjaan Umum dan Perumahan Rakyat (2018) Statistik semen nasional tahun 2010 - 2015: Kapasitas produksi semen nasional per tahun dari sistem informasi investasi dan pasar infrastruktur dari Direktorat Bina Investasi Infrastruktur, Dirjen Bina Konstruksi Kementerian Pekerjaan Umum dan Perumahan $R, w w w$.investasiinfrastruktur.net. Tersedia pada:

http://www.investasiinfrastruktur.net/semen.p hp?halaman = produksi $\quad$ (Diakses: $14 \quad$ Mei 2018).

Ganesan, K., Rajagopal, K. dan Thangavel, K. (2008) "Rice husk ash blended cement: Assessment of optimal level of replacement for strength and permeability properties of concrete," Construction and Building Materials, 22(8), hal. 1675-1683.

doi: 10.1016/j.conbuildmat.2007.06.011.
Habert, G., d'Espinose de Lacaillerie, J. B. dan Roussel, N. (2011) "An environmental evaluation of geopolymer based concrete production: Reviewing current research trends," Journal of Cleaner Production, 19(11), hal. 1229-1238.

doi: 10.1016/j.jclepro.2011.03.012.

Hardjito, D., Wallah, S. E., Sumajouw, D. M. J. dan Rangan, B. V. (2004) "On the development of fly ash-based geopolymer concrete," $\mathrm{ACl}$ Materials Journal, 101(6), hal. 467-472.

He, J., Jie, Y., Zhang, J., Yu, Y. dan Zhang, G. (2013) "Synthesis and characterization of red mud and rice husk ash-based geopolymer composites," Cement and Concrete Composites, 37, hal. 108-118. doi: 10.1016/j.cemconcomp.2012.11.010.

Kumar, S., Kumar, R., Alex, T. C., Bandopadhyay, A. dan Mehrotra, S. P. (2005) "Effect of mechanically activated fly ashabu terbang on the properties of geopolymer cement," in Proceeding of the World Congress Geopolymer Chemistry and Sustainable Development. Saint Quentin: Institut Géopolymère, hal. 113-116.

Liu, J., Shi, C., Ma, X., Khayat, K. H., Zhang, J. dan Wang, D. (2017) "An overview on the effect of internal curing on shrinkage of high performance cement-based materials," Construction and Building Materials, 146, hal. 702-712. doi: 10.1016/j.conbuildmat.2017.04.154.

Lura, P., Jensen, O. M. dan Igarashi, S.-I. (2007) "Experimental observation of internal water curing of concrete," Materials and Structures, 40(2), hal. 211-220. doi: 10.1617/s11527006-9132-x.

Nawy, E. G. (1998) Beton bertulang: Suatu pendekatan dasar. Bandung: Refika Aditama.

Posi, P., Teerachanwit, C., Tanutong, C., Limkamoltip, S., Lertnimoolchai, S., Sata, V. dan Chindaprasirt, P. (2013) "Lightweight geopolymer concrete containing aggregate from recycle lightweight block," Materials \& Design (1980-2015), 52, hal. 580-586. doi: 10.1016/j.matdes.2013.06.001.

Provis, J. L. dan van Deventer, J. S. J. (2009) Geopolymers: Structures, processing, properties and industrial applications. CRC press, Woodhead Publishing.

Ravikumar, D., Peethamparan, S. dan Neithalath, N. (2010) "Structure and strength of $\mathrm{NaOH}$ activated concretes containing fly ash or 
GGBFS as the sole binder," Cement and Concrete Composites, 32(6), hal. 399-410. doi: 10.1016/j.cemconcomp.2010.03.007.

Roy, D. M. dan Idorn, G. M. (1982) "Hydration, structure, and properties of blast-furnace slag cements, rortars, and concrete," Journal of the American Concrete Institute, 79(6), hal. 444457.

Shi, C. (1996) "Strength, pore structure and permeability of alkali-activated slag mortars," Cement and Concrete Research, 26(12), hal. 1789-1799.

doi: 10.1016/S0008-8846(96)00174-3.

Shi, C., Jiménez, A. F. dan Palomo, A. (2011) “New cements for the 21st century: The pursuit of an alternative to Portland cement," Cement and Concrete Research, 41(7), hal. 750-763. doi: 10.1016/j.cemconres.2011.03.016.

Susanti, R. dan Jatmiko, B. P. (2018) Dua tahun terakhir Indonesia kelebihan pasokan semen, Kompas.com. Tersedia pada: https://ekonomi.kompas.com/read/2018/04/0 5/114859526/dua-tahun-terakhir-indonesiakelebihan-pasokan-semen (Diakses: 24 Mei 2019).

Tangchirapat, W., Buranasing, R., Jaturapitakkul, C. dan Chindaprasirt, P. (2008) "Influence of rice husk-bark ash on mechanical properties of concrete containing high amount of recycled aggregates," Construction and Building Materials, 22(8), hal. 1812-1819.

doi: 10.1016/j.conbuildmat.2007.05.004.

Venkatanarayanan, H. K. dan Rangaraju, P. R. (2015) "Effect of grinding of low-carbon rice husk ash on the microstructure and performance properties of blended cement concrete," Cement and Concrete Composites, 55, hal. 348-363.

doi: 10.1016/j.cemconcomp.2014.09.021.

Wallah, S. E. (2009) "Drying shrinkage of heatcured fly ash-based geopolymer concrete," Modern Applied Science, 3(12). doi: 10.5539/mas.v3n12p14.

Wojsz, R. dan Rozwadowski, M. (1987) "An attempt to determine the function defining capillary structure of microporous adsorbents," Chemical Engineering Science, 42(12), hal. 2877-2881. doi: 10.1016/00092509(87)87053-7.

Xu, H. dan Van Deventer, J. S. J. (2000) "The geopolymerisation of alumino-silicate minerals," International Journal of Mineral Processing, 59(3), hal. 247-266. doi: 10.1016/S0301-7516(99)00074-5. 